\title{
STUDYING IN THE PAXOS ZONE THE CARBONATE DEPOSITIONAL ENVIRONMENT CHANGES DURING UPPER CRETACEOUS, IN SAMI AREA OF KEFALLINIA ISLAND, GREECE
}

\author{
Zoumpoulis E. ${ }^{\text {, Pomoni-Papaioannou F. }}$, Zelilidis A. ${ }^{1}$ \\ ${ }^{1}$ University of Patras, Department of Geology, Laboratory of Sedimentology, 26500, Patras, Greece, \\ elzoumpouli@upatras.gr,a.zelilidis@upatras.gr \\ ${ }^{2}$ Department of Geology and Geoenvironment,Section of Historical Geology and Palaeontology, \\ National University of Athens, Panepistimiopolis, 15784 Athens, Greece,fpomoni@ geol.uoa.gr
}

\begin{abstract}
The shallow-marine carbonate sequence of Sami (Kefallinia isl.Fig. 1) is a part of the Upper Cretaceous carbonate platform of the Paxi zone. Detailed lithostratigraphic and microfacies analysis of that sequence revealed clear periodicities and cyclicity. The high-resolution stratigraphic analysis has shown a number of lithofacies organized in groups (lithofacies associations), suggesting, on the whole, sedimentary environments ranging from lagoonal to peritidal context. The vertical arrangement of these lithofacies allowed the identification of a cyclic recurrence of the depositional and early diagenetic features, including a meteoric overprint on top of the elementary cycles. The cycles exhibit a shallowing upward trend from shallow subtidal to inter-supratidal and hypersaline facies, in a warm shallow marine environment.
\end{abstract}

Key words: peritidal carbonate, Upper Cretaceous, Paxi zone, Kefallinia.

\section{Introduction}

Peritidal carbonates are shallow-subtidal, intertidal and supratidal sediments formed in marginal-marine and shoreline depositional environments. These carbonates settings include the deposits of tidal flats, sabkhas, and shallow subtidal areas such as lagoons (Flügel, 2004). They have an important economic significance, for not only do they act as hosts for metalliferous and non-metalliferous mineral deposits but may also form sources, seals, and reservoirs for hydrocarbons (Wright, 1984).

The peritidal deposits are easy to be recognized in outcrops and in thin sections. They are important paleo-bathymetric indicators, reflect sea-level fluctuations, and form the basis for evaluation of sedimentary cycles and stratigraphic sequences.

The recognition and interpretation of ancient marginal-marine carbonate is fundamentally depended on comparison with modern transitional-marine carbonate environments. This approach is very successful, but should be applied cautiously. Fine-laminated carbonates do not necessarily originate in tidal zones, and spar-filled voids in micritic rocks could have been formed in tidal zones as well as in various subtidal environments. The best way to overcome these difficulties is to use the whole set of facies criteria and take into consideration the changes in microfacies and the sedimentary structures within vertical sequences.

Ancient carbonate rocks are traditionally studied by dividing peritidal environments into subtidal, 


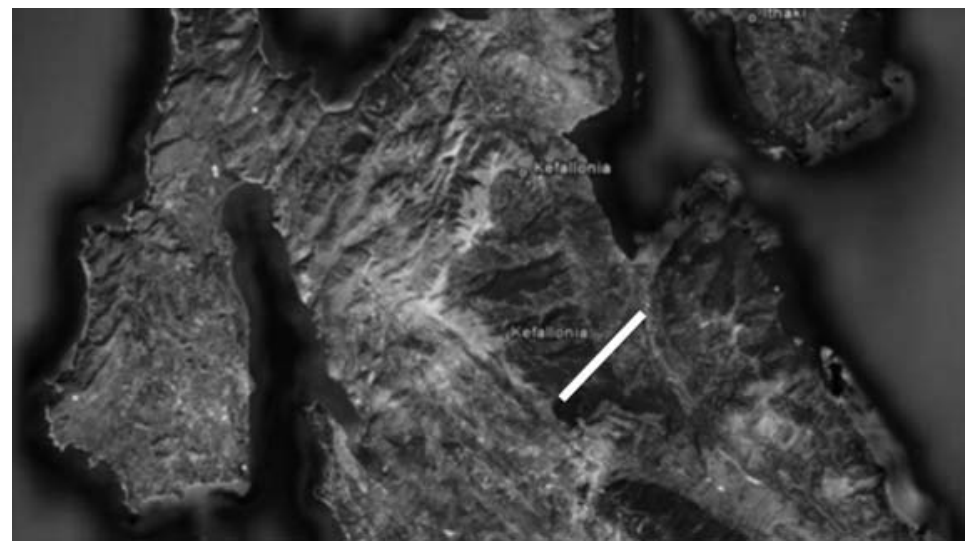

Fig. 1: Kefallinia Island. Simplified map showing the studied cross-sections.

intertidal and supratidal zones, despite the problems involved. Whether an area is subtidal, intertidal or supratidal depends on the tidal range, mean sea level.

According to Flügel (2004), subtidal sediments are seldom exposed to air. The term subtidal is restricted to those sediments seaward of a tidal flat system or within a system, such as in tidal channels. Intertidal sediments lie within normal high tide and normal low tide and they were exposed either once or twice daily normal, depending on the tidal regime and local wind conditions. Finally, supratidal sediments were deposited above normal or mean high tide and exposed to subaerial conditions most of the time because they were flooded only by spring and storm tides. Spring tides occur twice each month, and storm tides, the largest of all, occur sporadically during certain seasons and are less frequent.

Peritidal formations are commonly characterized by cyclicity. Cyclicity is a common feature of many limestone successions and occurs across different carbonate environments from platforms to reefs and down to basins. Understanding the origin of cyclicity in platform carbonates is crucial if cycles are to provide information on climate, eustacy and local tectonics, and if they are to be useful for high precision correlation. A cycle is a group of rock units that occur in a certain order, with one unit being frequently repeated through- out the succession. A stratifaction cycle is a group of beds which are regularly repeated. Regularity may be recorded by bed composition, repeated sequences of bed thicknesses, or constant number of beds composing the cycles. Many cycles are ascribed to corresponding, high- frequency and low amplitude sea-level changes (Flugel, 2004; Brescia et al., 1996; D’Argenio et al., 1997, 1999).

\section{Geological setting}

Kefallinia lies at the external (foreland) edge of the Hellenides fold-and-thrust system created in response to Cenozoic continental collision following closure of the Tethyan Ocean. The external Hellenides lie to the west of the Pindos thrust and are subdivided into three isopic zone: GavrovoTripolitza, Ionian, and Paxi zones. The Gavrovo-Tripolitza and Ionian zones have been considered to represent the external large Hellenide thrust sheets emplaced onto the stable Paxi autochthon as a part of the latest Hellenide events (Abouin and Dercourt, 1962; Temple, 1968; Jenkins, 1968; Smith and Moores, 1974; Underhill, 1989).

During the Early Mesozoic times, an extensive rifting had been developed in the western Greek territory, which due to the platform, in Early-Middle Jurassic times, was subdivided into ridges, and corresponded to the Gavrovo and Paxi zones, and basins, the Ionian and Pindos zones. Post-rift sedimentation 


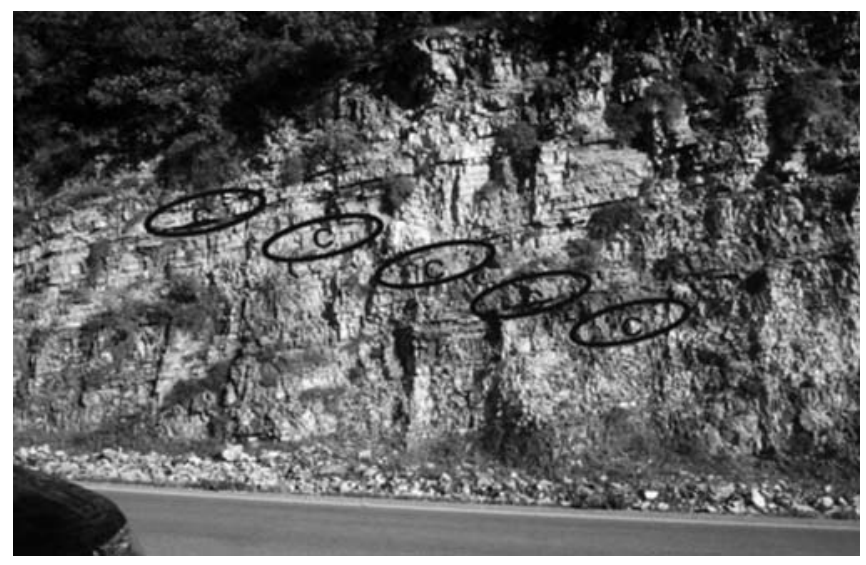

Fig. 2: The peritidal carbonate unit of the studied section (c: cycle).

persisted throughout the Cretaceous leading to the deposition of shallow marine carbonates on the ridges and deep-water carbonates in the basin (Tucker et al., 1990; Getsos, 2005; Getsos et al., 2007).

From the Triassic to the Upper Cretaceous, Western Greece was part of the Apulian continental block on the southern passive margin of Tethys. The island of Kefallinia is characterized by widely exposed Cretaceous limestones of the Paxi and Ionian zones, which were deposited at the margin of the Apulian carbonate platform. Sedimentary rocks in the Paxi zone consist of Triassic to Miocene deposits, mainly neritic carbonates. The Ionian zone comprises sedimentary rocks ranging from Triassic evaporites to Jurassic- Upper Eocene carbonate and minor cherts and shales which are overlain by Oligocene flysh (Karakitsios and Rigakis, 2007).

The Paxi zone forms the major part of the island of Kefallinia. It has been regarded as being the autochthonous foreland to the Hellenide fold-thrust belt which is generally believed to have been unaffected by major shortening (Aubouin, 1965; Jones 1968; British Petroleum Co. Ltd., 1971; Smith and Moores, 1974; Underhill, 1989).

Sami lies immediately to the west of the Ionian thrust and is composed entirely of thick Upper Cretaceous limestones that have been folded into a broad, open, northwest-southeast - trending pericline. The studied sections belong to the Paxi zone and lie across the main road Sami-Argostoli where well exposed outcrops occur. The aim of this work is to recognize depositional environment of a $27 \mathrm{~m}$ thick unit (part of the Cretaceous succession) which is composed of well-bedded limestone.

\section{Data collection and methodology}

Shallow-marine bedded carbonate sequences need a detailed sampling program, because they exhibit high microfacies variability due to changing subtidal and tidal depositional sites and common occurrence of cyclic sedimentation patterns. The study aims to understand of short- term changes in environmental of biota and sedimentation and for this reason an almost bed-to-bed sampling has been performed.

The studied area consists of 7 sections extending along 4-5 km and the thickness of the entire study area averages $150 \mathrm{~m}$. In total, 300 samples have been collected. In the present paper the data which are presented, resulted from the study of the fifth section which is $27 \mathrm{~m}$ thick (Fig. 2). Microfacies analysis is accompanied by X-ray diffraction analysis.

In the studied succession, the high-resolution stratigraphic analysis has shown a number of lithofacies organized in groups (lithofacies associations), suggesting, on the whole, sedimentary environ- 


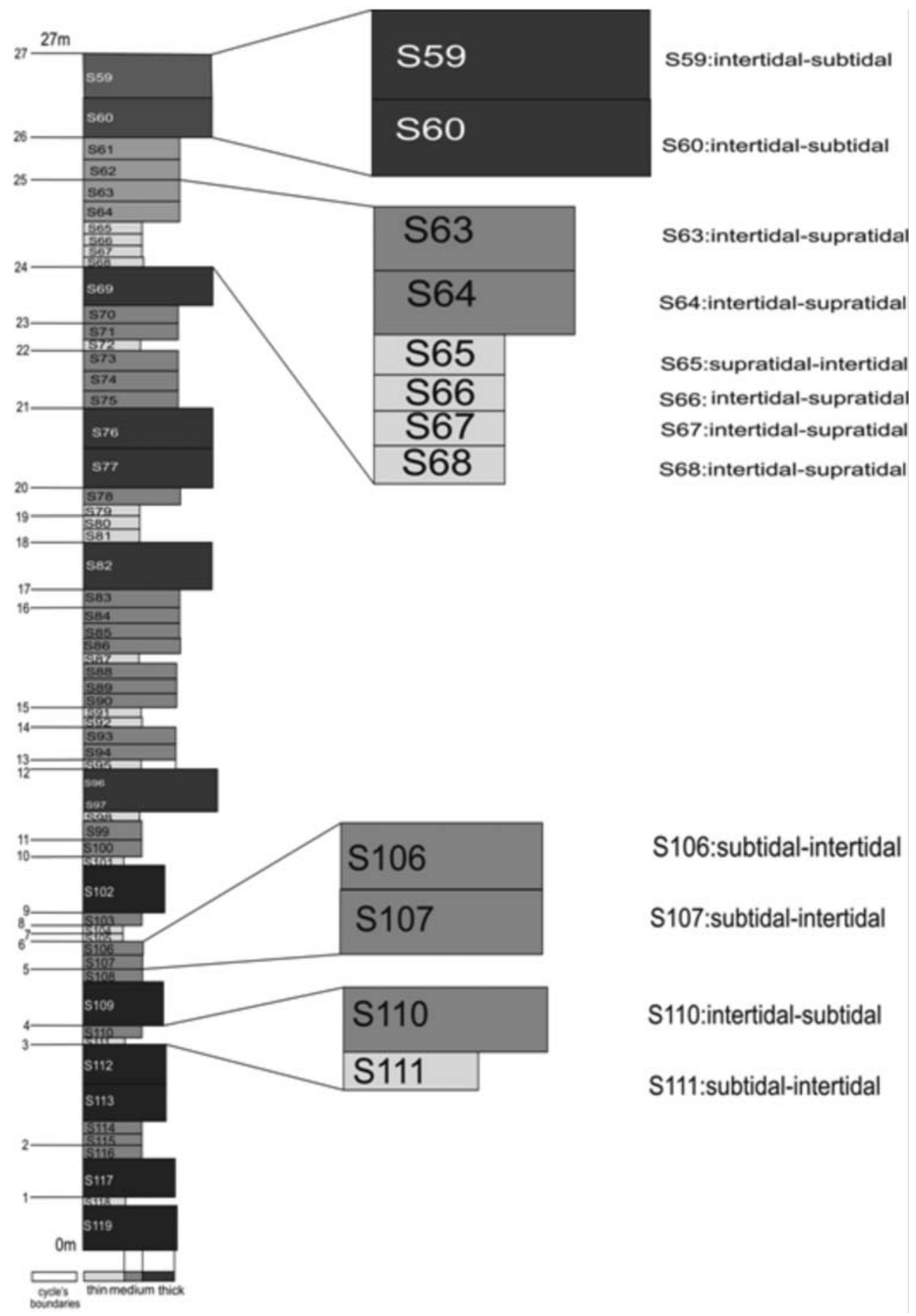

Fig. 3: The stratigrphic sequence of the studied section. Black color represents the thickly bedded limestones, grey color represents the medium bedded limestones and finally white represents the thinly bedded limestones. 


\begin{tabular}{|c|c|c|c|c|c|}
\hline Sample & Definition & Sample & Definition & Sample & Definition \\
\hline S59 & intertidal-subtidal & S81 & intertidal-supratidal & S103 & supratidal-intertidal \\
\hline S60 & intertidal-subtidal & S82 & subtidal-intertidal & S104 & subtidal \\
\hline S61 & supratidal-intertidal & S83 & intertidal-supratidal & S105 & supratidal-intertidal \\
\hline S62 & supratidal-intertidal & S84 & intertidal-subtidal & S106 & subtidal-intertidal \\
\hline S63 & intertidal-supratidal & S85 & intertidal & S107 & subtidal-intertidal \\
\hline S64 & intertidal-supratidal & S86 & subtidal-intertidal & S108 & supratidal-intertidal \\
\hline S65 & supratidal-intertidal & S87 & intertidal-subtidal & S109 & supratidal-intertidal \\
\hline S66 & intertidal-supratidal & S88 & subtidal-intertidal & S110 & intertidal-subtidal \\
\hline S67 & intertidal-supratidal & S89 & subtidal-intertidal & S111 & subtidal-intertidal \\
\hline S68 & intertidal-supratidal & S90 & subtidal-intertidal & S112 & supratidal \\
\hline S69 & shallow subtidal & S91 & intertidal-supratidal & S113 & intertidal-supratidal \\
\hline S70 & subtidal-intertidal & S92 & intertidal-supratidal & S114 & intertidal-supratidal \\
\hline S71 & intertidal-supratidal & S93 & subtidal-intertidal & S115 & intertidal-supratidal \\
\hline S72 & supratidal-intertidal & S94 & intertidal & S116 & subtidal \\
\hline S73 & subtidal & S95 & supratidal-intertidal & S117 & subtidal-intertidal \\
\hline S74 & intertidal-subtidal & S96 & subtidal & S118 & intertidal-supratidal \\
\hline S75 & intertidal-subtidal & S97 & subtidal & S119 & intertidal-supratidal \\
\hline S76 & shallow subtidal & S98 & subtidal-intertidal & & \\
\hline S77 & subtidal & S99 & intertidal-subtidal & & \\
\hline S78 & subtidal-intertidal & $\mathbf{S 1 0 0}$ & intertidal-supratidal & & \\
\hline S79 & subtidal-intertidal & S101 & intertidal-subtidal & & \\
\hline S80 & intertidal-supratidal & S102 & intertidal-subtidal & & \\
\hline
\end{tabular}

Fig. 4: The data of depositional environments in the studied area. They have been collected 60 samples, one sample for each bed. The thickness of the studied unit is $27 \mathrm{~m}$.

ments ranging from lagoonal to peritidal. The vertical arrangement of these lithofacies allows the identification of a cyclic recurrence of the depositional and early diagenetic features, including a meteoric overprint that may be observed on top of the elementary cycles.

\section{Facies analysis}

Peritidal carbonates have been observed in the Sami stratigraphic section. They are represented predominantly by micrites, often peloidal micrites. Common limestone types are mudstones, wackestones and bindstones. Intercalations of grainstones may be present in tidal channels, or as storm deposits. In the studied section subtidal, intertidal and supratidal zones are repeatedly observed overall the section forming shallowing-upward cycles (Figs. 3 and 4). High-frequency cyclicity, is ubiquitous in the studied Cretaceous shallow-water carbonates. The cycles seem to correspond to group of beds.

By studying the carbonate unit of the Sami stratigraphic section we attemted to understand their depositional settings and to distinguish between subtidal, intertidal and supratidal carbonates, by focusing on diagnostic criteria.

High-frequency sea-level fluctuations best explain this cyclic organization because shallow subtidal facies predominate, and emersion-related features are superimposed directly on subtidal (rarely on tidal) sediments (Buonocunto et al., 1994, 1999; D’Argenio et al., 1997, 1999; Raspini, 1998; Pomoni-Papaioannou, 2008; Pomoni-Papaioannou \& Kostopoulou, 2008).

\subsection{Subtidal}

This zone below the intertidal zone is permanently submerged. Water depth is a few meters. The subtidal zone is conventionally subdivided into a shallow and a deeper subtidal zone. The shallow subti- 


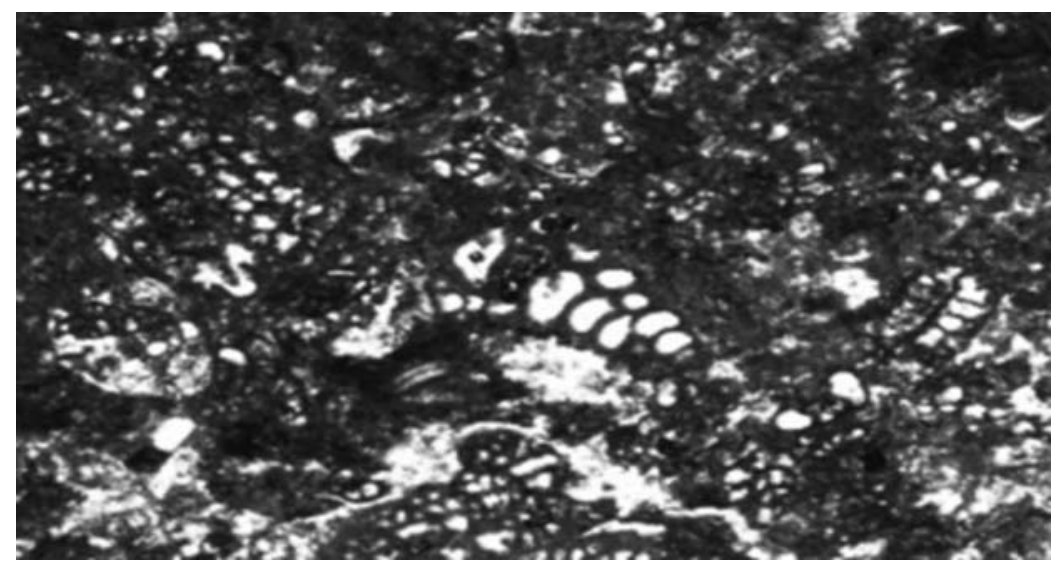

Fig. 5: Packstone with benthic foraminifera: subtidal.

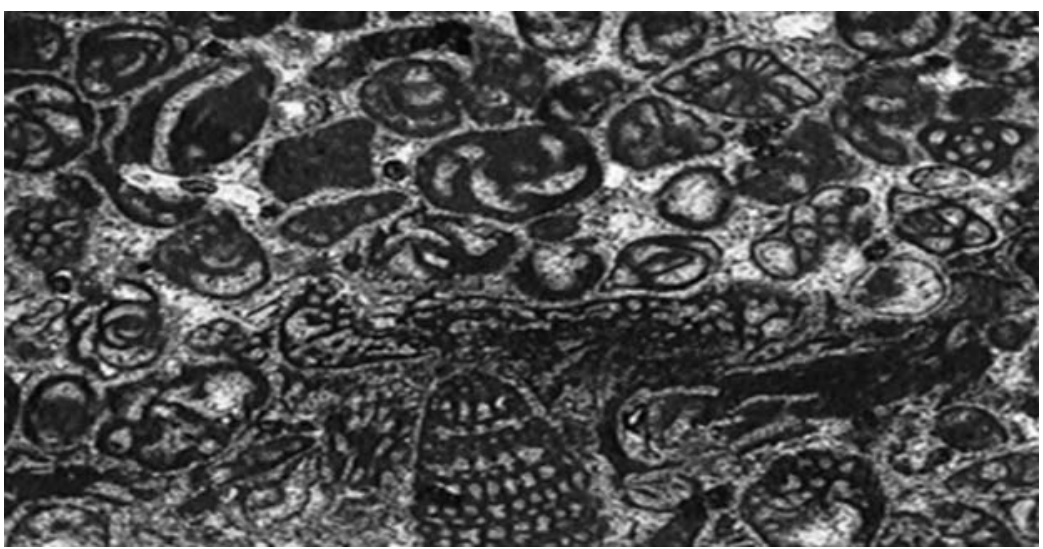

Fig. 6: Grainstone with benthic foraminifera (high energy environment) :subtidal.

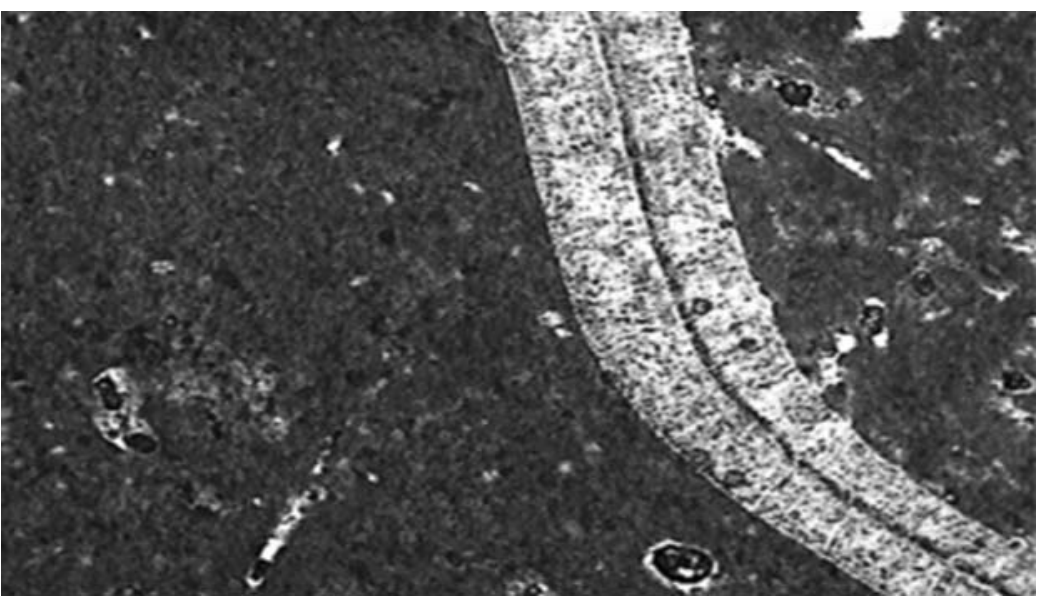

Fig. 7: Floatstone with rudist (low energy environment) :subtidal. 


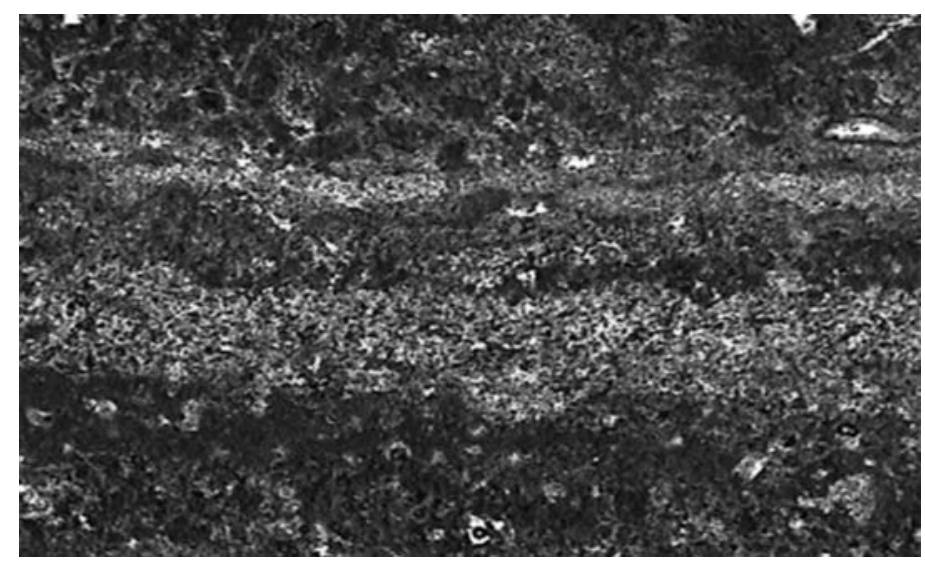

Fig. 8: Fine-laminated lime mudstone.

dal zone characterized by calcareous algae and invertebrates adapted to the phytal (e.g. foraminifera, bryozoans, worms). Epiphytes are common. Important indicators are the occurrence of dasyclad algae and encrusting organisms. The lower boundary, after comparison with recent zonations, can be drawn at approximately $30 \mathrm{~m}$. The deeper subtidal zone is characterized by high-diversity benthic organisms . Calcareous algae still occur (red algae). Dasyclads, however, are absent. The subtidal is characterized by burrowed and variably argillaceous lowest member. It consists of mudstone, wackestone or packstone (Fig. 5), often with a basal bio- or intraclastic grainstone (Fig. 6), as a transgressive lag on top of the preexisting succession. In subtidal zone lamination and teppes are absent. Mesozoic bivalves' bioclasts (rudist) occur, in places, which were adapted to euryhaline conditions. Rudist (Fig. 7) attributes the Late Cretaceous age of the studied deposits.

\subsection{Intertidal}

This zone is alternately flooded and exposed. Intermittent exposure is indicated by desiccation features, muddy surfaces with animal tracks and trails, and pores filled with vadose cement. Characteristic features of the intertidal regime are alternating erosion and deposition and rapid changes in current and wave velocity. These processes result in discontinuous sedimentation associated with scour-and-fill and the formation of channels, accumulation of reworked sediment, and substantial changes in grain size from lamina and bed to bed. The lower intertidal member exhibits thin-bedded, variably bioturbated mudstones, and bioclastic. In the studied section we observed repeated microbially laminated argillaceous mudstone/bindstone with small vertical desiccation cracks indicating the shallowest supratidal parts of the cycle (Fig. 8).

\subsection{Supratidal}

This is the most diagnostic zone in humid and arid tidal flats and represents the splash zone above high tide. It is flooded only a few times each month by spring tides or storms. Most of the sedimentation occurs above normal high tide during storm flooding. Diagnostic criteria for supratidal environment are:

- Evidence of subaerial exposure and pedogenetic influence.

- Evidence of cementation in the vadose zone.

The supratidal member is characterized by mudstones-wackestones with fenestral fabrics (Fig. 9), desiccation structures and thin interbeds of intraclastic packstone and laminae consisting of peloidal or bioclastic grainstone. Also the diversity of biota is very low. 

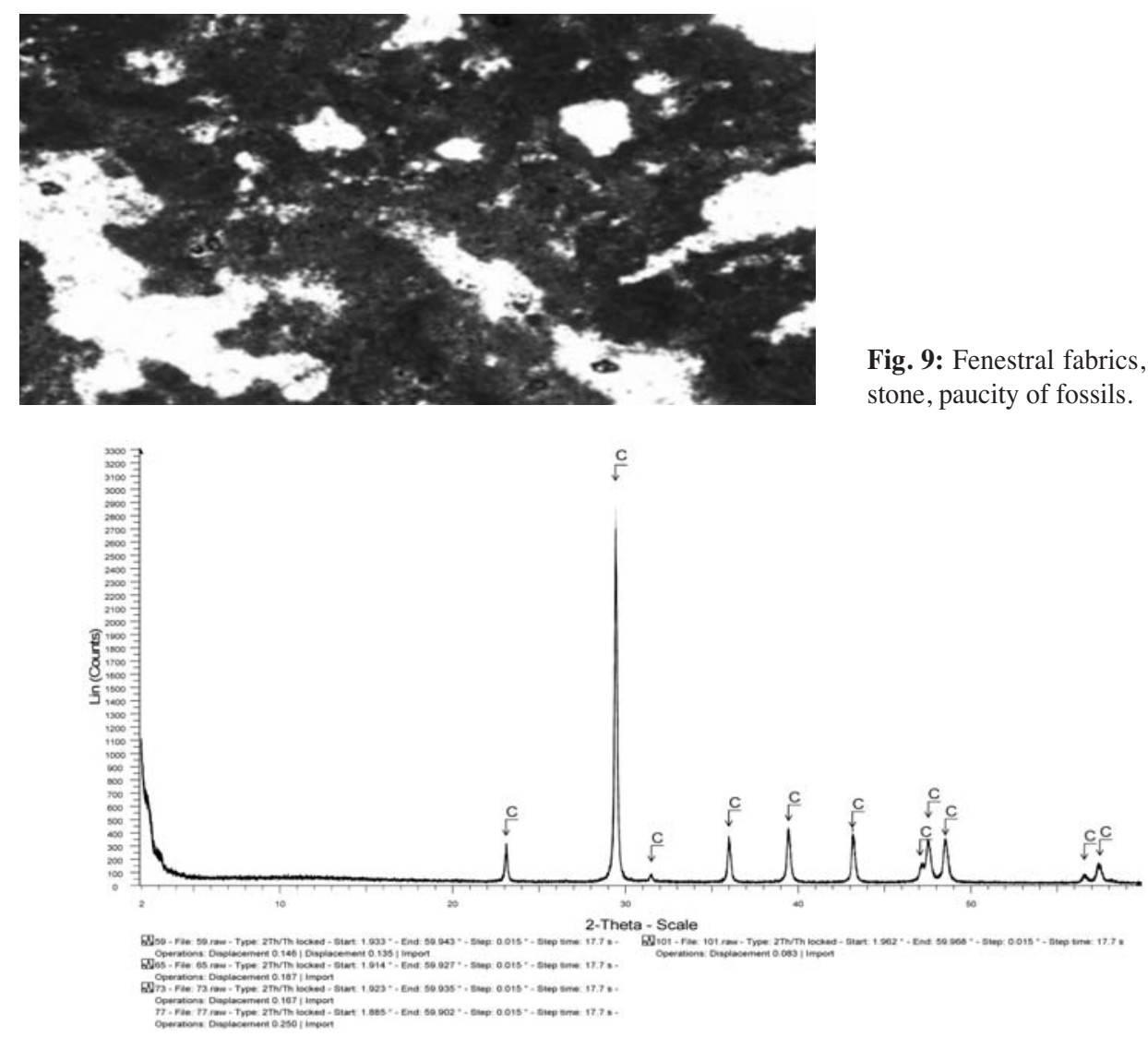

Fig. 10: X-Ray Diffraction pattern of bulk sample (samples S59, S65, S73, S77, S101). C: calcite.

\section{X-Ray Diffraction data}

Whole rock samples were analyzed by X-ray diffraction and consist of calcite (Fig. 10). The fraction soluble in $25 \% \mathrm{v} / \mathrm{v}$ acetic acid $\left(\mathrm{CH}_{3} \mathrm{COOH}\right)$ was determined for all samples following the method of Hirst $\&$ Nichols (1958). This fraction consists mainly of carbonate minerals, whereas the fraction insoluble in acetic acid consists of clay minerals. The clay minerals present are chlorite, illite and the mixed-layer clay minerals illite-smectite and chlorite-smectite. The preparation of the samples was based on the method Tsolis- Katagas (1987). Due to the low quantity of the clay fraction it is not possible to talk about early diagenetic features.

\section{Conclusion}

In the Upper Cretaceous studied unit of the carbonate succession, up to $27 \mathrm{~m}$ thick, a number of welldeveloped subaerial exposure surfaces and palaeosols have been recognized, that display strong evidence of vadose diagenesis and terrestrial conditions.

The high-resolution stratigraphic analysis has shown a number of lithofacies organized in groups (lithofacies associations), suggesting, on the whole, sedimentary environments ranging from lagoonal to peritidal context. The vertical arrangement of these lithofacies allowed the identification of a cyclic recurrence of the depositional and early diagenetic features, including a meteoric overprint on top of the elementary cycles. 
Small-scale cycles, formed in a low-energy peritidal environment, are characterized by the repetitive stacking of the facies types. The cycles exhibit a shallowing upward trend from shallow subtidal to intersupratidal and hypersaline facies, in a warm shallow marine environment. The presence of cyclic sedimentary record in the studied carbonate platform deposits display facies patterns changes that might have been caused in response to fluctuations in eustatic sea level.

\section{Acknowledgments}

We would like to thank the Section of Earth Raw Materials, Department of Geology, University of Patras, for the X-Ray diffraction method. Eleni Koutsopoulou is thanked for the definition of clay minerals. We thank P. Tsolis-Katagas for her constructive comments.

\section{References}

Aubouin, J., Decourt, J., 1962. Zone preapulienne et zone du Gavrovo en Peloponnese occidental. Bulletin de Société Geologique de la France. v.4 p.785-794.

Brescia, M., D’Argenio, B., Ferreri, V., Pelosi, N., Rampone, S. and Tagliaferri, R. 1996. Neural net aided detection of astronomical periodicities in geologic records. Earth Planet. Sci.Lett., 139, 33-45.

Buonocunto, F.P., D’Argenio, B., Ferreri, V. and Raspini, A. (1994). Microstratigraphy of highly organized carbonate platform deposits of Cretaceous age. The case of Serra Sbregavitelli (Matese, central Apennines). Giorn. Geol., 56, 179-192.

Flügel, E. 2004. Microfacies Analysis of Carbonate Rocks. Springer Verlag, Berlin, 745pp.

Getsos, K. 2005. PhD. University of Patras Publication.

Getsos, K., Pomoni-Papaioannou, F. \& Zelilidis, A. 2007. A carbonate ramp evolution in the transition from the Apulia platform to the Ionian basin during Early to Late Cretaceous (NW Greece). Proceedings of the 11th Intern. Congress of the Geological society of Greece, Bull of the Geol. Soc. Greece, XXVII, 53-63.

Jenkyns, D.A.L. 1972. Structural development of western Greece. American Association of Petroleum Geologists Bulletin v. 56. P.128-149.

Jones, W.D.V., 1968. Results of recent geological surveys in central-western Greece. Geological Society of London Proccedings v. 1645. p.306-310.

Karakitsios, V. 1992. Ouverture et inversion tectonique du basin Ionien (Epire, Grèce). Annales Géologiques des Pays Helléniques, v. 35, p. 185-318.

Karakitsios, V. 1995. The Influence of Preexisting Structure and Halokinesis on Organic Matter Preservation and Trust System Evolution in The Ionian Basin, Northwest Greece. AAPG Bulletin, v. 79, $\mathrm{n}$ 7,p. 960-980.

Karakitsios, V., Rigakis N. 2007. Evolution and petroleum potential of western Greece. Journal of Petroleum Geology, Vol. 30 (3), pp 197-218.

Pomoni-Papaioannou, F. 2008. Facies analysis of the Lofer cycles (Upper Triassic), in Argolis Peninsula(Greece). Sedimentary Geology, 208, 79-87.

Pomoni-Papaioannou, F. \& Kostopoulou, V. 2008. Microfacies and cycle stacking pattern in Liassic peritidal carbonateplatform strata, Tripolitza-Gavrovo platform, Greece Facies, 54, 417-431.

Smith, A.G., and Moores, E.M.1974. Hellenides, in Spencer-Verlag. Mesozoic and Cenozoic orogenic belts. Geological Society of London Special Publication 4. p. 159-185.

Tsolis-Katagas, P. 1987. Clay Minerals, X-Ray Diffraction. University of Patras Publication.

Underhill, J., 1989.Late Cenozoic deformation of the Hellenide foreland western Greece. Geological Society of America Bulletin, v. 101, p. 613-634.

Wright, V.P., 1984. Peritidal carbonate facies models: A review. Geological Journal vol. 19, 309-325. 
